\title{
CLIMATE AND WEATHER IMPACTS ON AGRICULTURE: THE CASE OF BRAZIL
}

\author{
Paula Pereda * \\ DENISARD ALVES ${ }^{\dagger}$
}

\begin{abstract}
The world's population will rise exponentially in the coming decades, increasing the demand for food and challenging the agricultural sector to ensure food security. Due to the importance of climate conditions for agriculture, this article analyzed two different hypotheses regarding climate impacts on agricultural markets in Brazil. First, farmers only observe the average climate conditions of their region when deciding the type and amount of crop or animal to grow or raise. Second, weather diversions from normal climate conditions cause farmers to deviate from optimal profits. Neither hypothesis was rejected by the data. The 2006 estimated loss from rainfall anomalies was 12.8 billion dollars (in 2014 values).
\end{abstract}

Keywords: translog profit function; climate change; climate and weather impacts; profit frontier; agricultural economics.

\section{Resumo}

A população mundial crescerá exponencialmente nas próximas décadas,o que desafiará o setor agrícola a garantir segurança alimentar. Devido à importância das condições climáticas para a produtividade agrícola, esse artigo testa duas hipóteses sobre o efeito do clima no mercado agrícola brasileiro. Primeiro, produtores observam as condições climáticas médias quando decidem o que e quanto produzir. Segundo, anomalias climáticas desviam os produtores do lucro ótimo. Nenhuma das hipóteses foi rejeitada pelos dados. A perda estimada pelo modelo das anomalias de chuva foi de US $\$ 12,8$ bilhões.

Palavras-chave: função lucro translog; mudanças climáticas; impactos do clima; fronteira de lucro; economia agrícola.

JEL classification: D21; Q11; Q12; Q54; Q56.

DOI: http://dx.doi .org/10.11606/1980-5330/ea119584

\footnotetext{
* Corresponding author: Department of Economics, USP. Av. Prof. Luciano Gualberto, 908, FEA2, 218 - Cid. Universitaria - Sao Paulo, Brazil, CEP: 05508-010. Email: pereda@usp.br. Phone: +55 11 3091-1796.

† University of Sao Paulo. Email: dcoalves@usp.br.
} 


\section{Introduction}

This study aimed to measure specific climate effects on agriculture because climate is an important factor influencing agricultural production. Climate is assumed to affect agricultural production on two different temporal scales: in the long-term because historical climate may be a direct input for crop and animal production affecting land use configuration, and in the short-term because weather conditions are an important determinant of crop/livestock failure and loss of productivity ${ }^{1}$.

The central idea of this analysis was that long-term climate influences the planning decisions of producers, while short-term weather events move production away from the production frontier. Thus, this study employs a stochastic profit framework in the empirical analysis and treats short- and long-term climate effects separately. The theory of how stochastic frontiers models relate to long-term and short-term models of producer behavior is currently underdeveloped, so this study addresses this deficiency while also discussing an important matter for public policy.

The following question is addressed in this study: how do climate and weather variables relate to the long-term and short-term problems of the agricultural producer? The answer to this question not only contributes to the current debate on how expected climate change may influence future human activities $^{2}$, but also addresses the efficacy of propositions for short-term actions intended to reduce climate variability effects on poor communities. Climate variations are expected to adversely affect food availability and generate significant losses, likely affecting small farmers and poorer populations the most ${ }^{3}$. The policy actions taken to reduce harmful climate impacts should rely on consistent estimations that take into account long-term trends as well as short-term weather changes that affect the production outcome.

This study focused on Brazilian farming and livestock breeding. Brazil is one of the leading grain producers and exporters in the world. The country has continental dimensions with correspondingly large climate variability from the equatorial North to the temperate South, 4 thousand kilometers away. The effects of climate and weather on production are distinguished by the frontier framework using a translog profit frontier approach. The results corroborate the hypothesis, showing that temperature seems to be more important than rainfall in the long-term, while rainfall more adversely affects agricultural production in the short-term. Simulations indicated that rainfall levels much lower than historical average, such as that observed during the Summer of 2005 and 2006, caused a loss of 5.6\% in farm profits in 2006, accounting for almost 12.4 billion dollars (in 2014 values). This can be interpreted as the farmers' maximum willingness to pay to protect themselves against the unforeseen rainfall shortcomings in Brazil during that year.

\footnotetext{
${ }^{1}$ As caused by droughts, frosts, hail, severe storms and floods. In 2012 , the soybean production in South America was 3\% below the expected level due to adverse weather conditions (Valor-Econômico (2012)).

${ }^{2}$ Climate change involves an evolution in the distribution of climate over time, which may affect long-term average conditions as well as the variation of climate (IPCC (2007))

${ }^{3}$ Rosenzweig \& Wolpin (1993) found that extreme weather events contribute indirectly to the existence of rural poverty, as poor (small) farmers avoid taking risks or spending assets under the threat of extreme weather events. This limits their productivity gains through investment in capital and innovations (Rosenzweig \& Binswanger 1993).
} 


\section{Theoretical Background}

\subsection{Agricultural Approach}

Studies measuring the impact of climate on agricultural outcomes are usually based on the following two different modeling approaches: The Ricardian or hedonic approach (Mendelsohn et al. 1994, Deschenes \& Greenstone 2007) and the agronomic or crop approach (Lang 2001). While the former measures the influence of climate on land values, the latter uses the farmers' production structure to measure the optimal allocation of different crops to inputs and fixed factors. The choice between these two approaches is based on their relative advantages and disadvantages and their data requirements. Some authors argue that studies following the Ricardian approach produce more aggregated results, which may be an obstacle for the measurement and the proposal of adaptation measures (Deschenes \& Greenstone 2007). This study adopted an agro-economic approach to identify the specific effects of climate on agricultural yields. The agro-economic literature bases this analysis on agricultural profits and production functions, which are briefly discussed here.

The next step is to understand how climate can be considered in this approach, as it impacts the model choice. Demir \& Mahmud (2002) argued that the local agro-climatic conditions are historically known by farmers, and therefore, should not be treated as random because they influence the producers' choices. As a result, changes in average climatic conditions can modify the behavior of farmers as they take into account local climate patterns such as temperature and precipitation to determine the output-input mix (Kumbhakar \& Lovell 2000, Kumar \& Parikh 2001). Assuming that farmers only observe past climate conditions (average climate), it seems reasonable to consider that the historical climate is an important input for crop and livestock outputs ${ }^{4}$.

Another relevant climate effect on agriculture is related to extreme weather events during growing and harvesting seasons, which are not observed by farmers when choosing the output-input mix that optimizes their outcomes. Those extreme events can cause important damages which divert farmers from their optimal allocation. The errors/deviations in the production decision are translated into lower profits for producers, causing inefficiencies (Ali et al. 1994). This short-term climate concern has led to the use of an efficiency analysis which measures and helps to identify variations in the physical and financial performance achieved by farmers operating with the same environmental and economic constraints (Wilson et al. 2001).

Ali \& Flinn (1989) argued that to measure efficiency, a production function approach may not be appropriate when the population of farmers faces different prices and has different factor endowments ${ }^{5}$. When facing heterogeneous farms, the authors urge the use of stochastic profit function models.

\footnotetext{
${ }^{4}$ We assume that farmers do not have accurate information about the next season's climate. The arguments in favor of this hypothesis are: (i) access to short-term forecasts is higher among large and medium farmers, who represent a small proportion of total farmers, and (ii) the longer the weather forecast horizon, the less accurate it will be. For perennial crops, livestock and forest products short-term forecasts might not be useful, although they are more relevant for annual crops.

${ }^{5}$ The production function approach might be biased and inconsistent if the profit maximization is valid, since the input mix is dependent on the error term of the production function (Coelli 1995).
} 
The stochastic profit function model, or profit frontier approach, in addition to providing a compact form to summarize a multiproduct technology ${ }^{6}$, is an effective way to introduce theoretical constraints into the analysis. Next, the theoretical and empirical developments are detailed, which support the measurement of the intended effects.

\subsection{Profit Frontier Approach}

It was assumed that producers allocate their variable inputs $(g)$ to types of production $(s)$. The products $(m)$ considered in the analysis are such that $m=$ $s+g$. Producers decide production and total inputs by solving a variable profit maximization problem in a competitive market. Thus, prices are exogenous. Each producer also faces quasi-fixed inputs (exogenous variables in the shortterm), represented by $\left(Z=\left(Z_{1} \ldots, Z_{f}\right)^{\prime}\right)$, which affect the farmer's decision $(q=$ $\left.\left(q_{1}, \ldots, q_{m}\right)^{\prime}\right){ }^{7}$ The $Z$ vector includes other exogenous variables such as local climate patterns in temperature and rainfall and the user of technology by the farm.

Producers maximize a short-term profit function, or a restricted profit function, by choosing the allocation of multiple outputs and inputs given an endowment of fixed factors $Z$ and $p$. By replacing the optimal solution $q^{*}$ in the profit $(\Pi)$ function, the optimal profit function can be described as $\Pi^{*}(p, Z)$, depending on the exogenous variables prices and other quasi-fixed inputs. In this model, because markets are perfect, there are no losses and farmers are fully efficient in optimizing profit.

Kum-bhakar \& Lovell (2000) relaxed the assumption of full efficiency because inefficient farmers can survive in the short-term. Assuming that the correct relative market prices are observed by the farmers, all farmer inefficiency comes from technical issues. Considering the potential inefficiencies $(\tau)$ in the profit function and assuming the transcendental logarithm (translog) function for farmers' restricted profit function (Christensen et al. 1975), the translog profit frontier normalized at product 1 is:

$$
\begin{aligned}
\ln \left(\frac{\Pi}{p_{1}}\right)= & \beta_{0}+\sum_{j>1} \beta_{j} \ln \left(p_{j} / p_{1}\right)+\frac{1}{2} \sum_{j>1} \sum_{k>1} \beta_{j k} \ln \left(p_{j} / p_{1}\right) \ln \left(p_{k} / p_{1}\right)+ \\
& \sum_{j>1} \sum_{r} \gamma_{j r} Z_{j r} \ln \left(p_{j} / p_{1}\right)+\sum_{r} \delta_{r} Z_{r}+\frac{1}{2} \sum_{h} \sum_{r} \theta h r Z_{h} Z_{r}-\tau
\end{aligned}
$$

In which $j, k=1, \ldots, m ; r, h=1, \ldots, f$; and $\beta, \delta, \theta, \gamma$, and $\tau$ are parameter vectors. The normalized translog functional form generates a closed-form solution.

Note that $\tau$ is a non-negative component that shifts the profit from the optimum. To estimate this equation, Kum-bhakar \& Lovell (2000) suggested a maximum likelihood estimation using the probability density function (pdf) of the composite error $\left(-\tau_{i}+v_{i}\right)^{8}$. Thus, assuming independence among the

\footnotetext{
${ }^{6}$ According to Kum-bhakar \& Lovell (2000), profit analysis offers a more complete approach as it better characterizes the production structure and technologies.

${ }^{7}$ The vector $q$ denotes the products amounts: $q_{j} \geq 0$, when $j$ is an output; $q_{k} \leq 0$ and when $k$ is an input.

${ }^{8}$ When $v_{i}$ is i.i.d. and follows $N\left(0, \sigma_{v}^{2}\right)$ and $\tau_{i}$ is i.i.d. and follows $N^{+}\left(\mu, \sigma_{\mu}^{2}\right)$, the pdf of the composite error can be found (DeGroot \& Schervish 2012)
} 
observations, the log-likelihood is implemented in Stata and the translog profit frontier can be estimated ${ }^{9}$.

One of the advantages of using the normalized translog functional form is the flexibility of testing and assuming the theoretical hypothesis to ensure that producers are maximizing profits. Therefore, the profit frontier equation can be estimated by imposing the symmetry and homogeneity assumptions. Another relevant piece of information from the model is that farmers from different climate conditions in the sample could change the technical use of quasi-inputs and inputs due to distinct local climate conditions. In this context, different behaviors among farmers allow for the analysis of adaptation to the expected climate change through the calculation of possible compensatory responses to climate variations.

\section{Efficiency Analysis}

$\tau$ measures the shifts of profit away from the optimum, or the failure of the farmer to reach the maximum possible profit as follows: $\tau=\ln \Pi^{*}(p, Z)-\ln \Pi$, $j=1,2, \ldots, m$; in which $\Pi$ is the actual profit level achieved and $\tau \geq 0$ is the inefficiency term. This measure can be interpreted as the intrinsic total profit/technical inefficiency of each farmer. Thus, the TE ratio is the loss of profits from not producing the desired production levels:

$$
T E=\exp (-\tau)=\frac{\Pi(p, Z)}{\Pi^{*}(p, Z)}
$$

As $\tau \geq 0$, the measure of TE varies from zero, the least efficient, to unity, fully-efficient. Kum-bhakar \& Lovell (2000) proposed an unbiased estimator for $T E$, considering that the determinants of the $T E$ should be uncorrelated with the covariates of the profit function. Within this context, Battese \& Coelli (1995) stated that efficiency can be explained by a set of exogenous variables. The authors proposed a joint estimation of the profit equation and the determinants equation, assuming that the average of $\tau_{i}(\mu)$ is a function of those determinants. This procedure eliminates possible inconsistencies, as $\tau_{i}$ is assumed to be identically distributed in the profit frontier equation. Thus, the $T E$ determinants equation is:

$$
T E_{i}=f\left(C_{i}, X_{i}, D_{i}\right)+\varepsilon_{i}
$$

In which $\varepsilon_{i}$ is a random shock with positive distribution for each farmer (representative farmer of municipality $i)^{10} ; C_{i}$ is a vector of climate anomalies (e.g., extreme weather variables) in the municipality $i$; $X_{i}$ is a vector of farmer characteristics; and $D_{i}$ is a vector of other determinants. Gorton \& Davidova (2004) divided the determinants into two groups: human capital and structural factors. The former group includes information on the farmers' manage-

\footnotetext{
${ }^{9}$ The derivative of the profit logarithm is the output/input profit shares $\left(s_{j}\right)$. Thus, the effects of prices and other exogenous variables can be measured by their estimated elasticities. The product $j$ 's elasticity in relation to the exogenous variable $r$ can be denoted by $\varepsilon_{j r}=z_{r}\left(\delta_{r}+\sum_{j>1} \gamma_{j r} \ln \left(p_{j} / p_{1}\right)+\frac{1}{2} \sum_{h} \theta_{h r} z_{h}+\frac{\gamma_{j r}}{s_{j}}\right)$.

${ }^{10}$ The local political unit in Brazil is the municipality, which is similar to a county except there is a single mayor and municipal council. There are no unincorporated areas in Brazil.
} 
ment, their characteristics and education ${ }^{11}$, while the latter group comprises environmental conditions, credit access ${ }^{12}$, rural infrastructure ${ }^{13}$ and information on property rights, among others.

In regard to environmental conditions, Kumar \& Parikh (2001) stated that weather deviations from normal conditions influence crop growth and, consequently, the TE of farmers. The work of Sherlund et al. (2002) found that the exclusion of climate variables in the determinants equation could lead to biased parameters. Demir \& Mahmud (2002) included environmental factors to explain efficiency differences. They emphasized that the omission of climate variables under the argument that they are beyond the farmers' control can lead to inaccurate interregional technical efficiency comparisons. They considered rainfall anomalies (i.e., rainfall above or below the national average) as one of the main determinants of technical inefficiency. In Brazil, Imori et al. (2012) found statistically significant impacts of temperature and precipitation on the estimated technical efficiency.

\section{Material and Methods}

This section presents the sources of the data used, the definition of variables for the model, and an overview of the proposed problem based on the collected data. Appendix A shows all descriptive statistics of the discussed variables.

\subsection{Data Sources: Profit Frontier}

The main agricultural data source in the country is the Brazilian Agricultural Census, conducted by the Brazilian Institute of Geography and Statistics (IBGE). The census aggregates farmers into administrative districts such as municipalities to preserve the identity of farmers. Additionally, data based on responses by fewer than three farm establishments are not reported for the same reason. Despite the loss of desired information on the individual choices of farmers, this procedure does not preclude this analysis, as there are local homogeneities among the grouped farmers (Disch 1985). Moreover, the price variability among regions is preserved. Pastore (1968) minimizes the aggregation problem when the model is estimated by using the information available for the smallest regional unit.

The last census was conducted in 2006, from January to December, and represents a cross-section of average municipal farmers. Panel data, which could generate more accurate results, were not used for two reasons: first,

\footnotetext{
${ }^{11}$ The literature identifies education and farming experience as the main farm management determinants (Xu \& Jeffrey 1998, Rahman 2005, Bozoğlu \& Ceyhan 2007). Another relevant variable that influences the efficiency of farmers is farm size (Ali et al. 1994, Ali \& Flinn 1989, Wang et al. 1996, Xu \& Jeffrey 1998, Tzouvelekas et al. 2001). Barrett (1996) points to an inverse relation of size and efficiency, as small farmers might use an exceptional amount of work to compensate the failures of product and credit markets that they observe.

${ }^{12}$ Helfand (2003) and Imori et al. (2012) posit that they can lead to non-optimal choices by farmers.

${ }^{13}$ Ahmed \& Hossain (1990) say that rural infrastructure is the key limiting determinant of efficiency. Other studies have identified this influence by calculating the impact of the distance to markets and extension services, agricultural infrastructure, and regional differences (Rahman 2005, Tzouvelekas et al. 2001) on inefficiency. Soil conditions might also have a positive or negative influence on productivity, as highlighted by Rahman \& Parkinson (2007).
} 
the data incompatibility between the collection periods of the last two agricultural censuses carried out in Brazil (2006 and 1995-96), and second, the different variables among the censuses. Moreover, in climate-agricultural studies, fixed effects could absorb most of the average climate conditions of the municipality (Fisher et al. 2012).

The 2006 Census contains information on the output and input quantities and values, land type and use, and farmer and farm characteristics, among other aspects. The agricultural products considered are divided into nine components in four groups with the share of the agricultural production value shown in parentheses: (i) annual crops $(52.7 \%)$ : soybeans, maize, and others; (ii) perennial crops $(20.3 \%)$ : coffee and others; (iii) livestock $(22.4 \%)$ : milk and beef cattle; and (iv) forest $(4.6 \%)$ : wood and other forest products.

These products were chosen according to their weight in terms of production value in $2006^{14}$. The choice of inputs was made using the same criteria, which selected four inputs: land and fuel as quasi-fixed inputs, and labor and fertilizers as variable inputs.

Farmers must have price expectations $\left(p^{e}\right)$ when deciding on the crops or animals to grow or raise and the amount of expected return. Rausser \& Just (1981) stated that the use of future prices performed better than econometric forecasts. However, future prices do not exist for all agricultural products and do not have regional variation. Barbosa (2011) assumed that the farmers' expectations are the average of real prices observed in the five years before the decision (adaptive expectations). This article tested Barbosa's estimated prices and also different weights by modeling each product price using a dynamic panel-data model. The superscript $\left({ }^{\mathrm{e}}\right)$ for prices will be omitted to simplify the equations.

The profit variable was measured using the difference between the sum of the agricultural production value of the products listed above (production in 2006 times the crop prices) and the sum of the costs of the fixed and variable inputs considered in the model. This measure includes the possible storage for that year as well as the total production value of the year, and not total sales. However, it does not account for other minor costs that might be omitted, such as farm household labor. This would cause a bias in climate estimates only if the average climate is correlated with such implicit costs.

The total amount of fuel used by the farm was considered a proxy for the capital stock of the farm. The fuel variable was generated by summing up the data on different energy sources. All types of fuels were converted into energy generation as kilocalories (Kcal), using the density and power capacity figures. In regard to labor variables, labor prices were calculated as the average rural wage equal to the sum of farm workers' monthly wages divided by the number of employees, including permanent workers, temporary workers, farm owners, and others.

The technological variables available in the 2006 Census were chosen based on the study of EMBRAPA (Empresa Brasileira de Pesquisa Agricola, the government agricultural research agency) and IBGE (2010). They mapped the following technological variables: use of irrigation, proportion of establishments with mechanical harvesters, municipalities with $50 \%$ or more of the

\footnotetext{
${ }^{14}$ Soybeans and maize represent $24.3 \%$ and $14.9 \%$ of the total value generated by annual crops, respectively; and coffee represents $34.9 \%$ of the value of perennial crops. Beef and milk production represent approximately $55 \%$ of livestock production value.
} 
harvested area planted with certified and transgenic seeds, municipalities with $50 \%$ or more of agricultural establishments having access to technical assistance, number of establishments with tilled area, number of establishments with eucalyptus production; and for livestock, municipalities that have establishments with artificial insemination, animal screening, use of industrial feed, and animal confinement. Most of this data is available in the 2006 Census.

Complementary data regarding Brazilian agriculture is available from the Municipal Agricultural Survey (PAM) conducted by IBGE, which collects annual crop production. This data was used for the price expectation estimations.

\subsection{Data Sources: TE Determinants Analysis}

Based on the TE determinants literature and data availability, a group of variables was selected for the study. These variables are described below:

\subsection{Data Sources: Climate}

The historical climate data for Brazil was obtained from the National Meteorology Institute (INMET), which collects information about average, minimum and maximum temperature, total precipitation (millimeters, days of rain), and relative humidity by weather stations. To transform the data from the stations into municipalities, the kriging method of interpolation was used (Haas 1990). For all the climatic variables, the average data for the seasons was calculated gathering the information over the months of each season. Climate information represents the average temperature, precipitation, and relative humidity of the season.

Long-term climate represents the average climate conditions of regions where patterns can be identified. An example of this is that the average precipitation in the Amazon Forest is higher than in the Northeast semiarid region, although both regions have the same high average temperatures throughout the year.

Short-term climate variations represent the annual climatic deviations from long-term conditions. These deviations are usually dominated by interannual and seasonal variations and are observed due to the oscillations of the Earth's climate system that impact weather patterns at the local, regional, and global levels.

The long-term average was calculated based on the past 30-year average data (from 1976-2005), namely E(climate). The use of such a long period is standard in climate studies to avoid the measurement of other specific climate cycles. The average was calculated by season. This article considered only average Summer and Winter seasonal climate information because Latin American countries in general do not have well-defined seasons. Thus, Summer and Winter are representative seasons in regard to a region's climate patterns (Cunha et al. 2014, Seo 2010, 2011, Seo \& Mendelsohn 2007).

In regard to short-term climate data, the 2005 and 2006 climate information by season (climate) was demeaned by the long-term climate data, E(clima$t e)$, and this deviation from long-term mean was divided by the standard deviation as calculated from the former 30 -year climate $\left(\sigma_{\text {climate }}\right)$ to standardize the climate information. Both years were used because the 2006 harvest de- 
Table 1: Complete description of variables and their sources

\begin{tabular}{|c|c|c|}
\hline Variable & Description & Source \\
\hline $\begin{array}{l}\text { Farmer education } \\
\text { and experience }\end{array}$ & $\begin{array}{l}\text { Percentage of local population that completed each education level, and the percentage of farmers, } \\
\text { by experience years, who run establishments: less than } 1 \text { year, } 1-5 \text { years, } 5-10 \text { years, over } 10 \text { years }\end{array}$ & $\begin{array}{l}\text { Demographic Census of } 2010 \\
\text { (IBGE) }\end{array}$ \\
\hline $\begin{array}{l}\text { Other farmer } \\
\text { characteristics }\end{array}$ & $\begin{array}{l}\text { Farmer gender, percentage of land owners, percentage of tenants/sharecroppers, soil type: per- } \\
\text { centage of non-agricultural land in the municipality (namely, degraded areas) }\end{array}$ & $\begin{array}{l}\text { Agricultural Census of } 2006 \\
\text { (IBGE) }\end{array}$ \\
\hline Farm size & $\begin{array}{l}\text { Average farms in the municipality in hectares per farm and percentage of family farms in the } \\
\text { municipality }\end{array}$ & $\begin{array}{l}\text { Agricultural Census of } 2006 \\
\text { (IBGE) }\end{array}$ \\
\hline $\begin{array}{l}\text { Production diversi- } \\
\text { fication }\end{array}$ & $\begin{array}{l}\text { The general Herfindahl-Hirschman Index (HHI) is calculated based on the value of production } \\
\text { among the following aggregated products: large animals, midsize animals, small animals, peren- } \\
\text { nial crops, annual crops, horticulture, forestry and plant extraction. The index represents agricul- } \\
\text { tural diversification. A zero value denotes perfect diversification, and a value of } 1 \text { (one) denotes } \\
\text { perfect specialization }\end{array}$ & $\begin{array}{l}\text { Agricultural Census of } 2006 \\
\text { (IBGE) }\end{array}$ \\
\hline Access to credit & $\begin{array}{l}\text { Percentage of establishments that obtained some type of loan from different sources (banks, co- } \\
\text { operatives, among others) }\end{array}$ & $\begin{array}{l}\text { Agricultural Census of } 2006 \\
\text { (IBGE) }\end{array}$ \\
\hline Altitude & Altitude in meters, which increases the risk of frosts & IBGE Cities and Towns (1998) \\
\hline Infrastructure & $\begin{array}{l}\text { Index for logistic cost to Sao Paulo in } 1995 \text {, updated in } 2009 \text {, based on the transportation costs } \\
\text { to the city of Sao Paulo, whose costs are a result of applying a linear programming procedure for } \\
\text { calculating the minimum shipping cost to Sao Paulo }\end{array}$ & NEMESIS (2009) \\
\hline $\begin{array}{l}\text { Membership in co- } \\
\text { operatives }\end{array}$ & Percentage of producers that are members of a cooperative, union or other similar associations & $\begin{array}{l}\text { Agricultural Census of } 2006 \\
\text { (IBGE) }\end{array}$ \\
\hline Pest control & $\begin{array}{l}\text { Percentage of agricultural establishments that perform pest control (biocontrol, burning waste, } \\
\text { use of repellents, among others) }\end{array}$ & $\begin{array}{l}\text { Agricultural Census of } 2006 \\
\text { (IBGE) }\end{array}$ \\
\hline
\end{tabular}


pended on the previous year's weather. The new variable can be interpreted as the climate anomaly or extreme weather intensity. Therefore, two subsets of indexes were created to test their impact on TE, and consequently, on profits: the drought index, which is the observed rainfall below the long-term average rainfall in standard deviations $Z_{D}<E($ Rain $)-\alpha \sigma_{\text {Rain }}$; and the cold stress in$\operatorname{dex}^{15}$, which is the observed air temperature below the long-term average in standard deviations $Z_{C}<E($ Temp $)-\alpha \sigma_{\text {Temp }}$. In this formulation, $\alpha$ represents the intensity of the extreme weather occurrence and all climate variables are transformed in terms of $\alpha$. These indexes were used to test the significance of the climate variables in the TE determinant equation to simulate the effects of extreme weather events on agriculture.

\section{Results}

The results were subdivided into the long-term analysis, which presents the results of the estimation of the profit frontier equation, and the short-term analysis, which discusses climatic effects on the farmers' profit deviation from the frontier profit function.

\subsection{Average Climate Impact on Profits}

The final estimated model is a normalized profit frontier model against all the prices and exogenous variables of the model and its interactions. The relevance of including climate variables in the profit model was tested by the likelihood ratio (LR) test. The LR statistic ranged from 863.43 to 949.65 depending on the price expectation used, indicating that average climate is necessary to explain farmers' profits at a $1 \%$ level of significance. The homogeneity and symmetry restrictions were automatically imposed by the translog specification. The convexity assumption was tested using an LR test, and the results indicated that, in general, the estimated profit function can be considered convex at $1 \%$ of significance level ${ }^{16}$.

By disaggregating the profit impacts into profit share effects, the climate variables showed important effects: low rainfall levels impacted only soybean profit shares, while places with higher average temperatures had negative effects on maize, coffee, and beef (Table 2$)^{17}$. Soybeans, other annual crops, and other forest products generate more profits when cultivated in smaller areas, as indicated by the land quantity effect. Higher irrigation means more profits for soybeans, maize, and coffee, the main crops analyzed in this article.

To further investigate the average climate impacts on agriculture, the model allows for the calculation of the semi-elasticities of supply for each climate

\footnotetext{
${ }^{15}$ The occurrence of frosts is due to a combination of low temperatures and moisture in the atmosphere. Frost may cause death of plants when it entails the freezing of plant parts. Temperatures above a specific range may cause worse effects. Normally, frosts are worse in the Winter and at medium and high latitudes and on higher altitude areas, mainly the south of Brazil and some higher areas in Sao Paulo and Minas Gerais states.

${ }^{16} \mathrm{Ho}$ : all $\beta_{j j}$ are zero; Ha: all $\beta_{j j}$ were statistically significantly above zero with 10 degrees of freedom and a Chi-square of 158.73 (statistically significant at $1 \%$ ). Individual tests were also performed. The estimated results were not statistically significant from zero or negative for three products: soybeans; beef; and maize. Note: The higher log-likelihood value was obtained by using the 5-year average price as the proxy for expected price by farmers.

${ }^{17}$ Note: Other results were suppressed from this article due to size limits, but can be requested from the authors.
} 
Table 2: Average partial effect of exogenous variables $(r)$ on profit shares by product $(j)$ from 2006 census

\begin{tabular}{|c|c|c|c|c|c|c|c|c|c|}
\hline $\begin{array}{l}\text { Effect on Profit } \\
\text { Shares by Output } \\
\left(\gamma_{j r}\right)\end{array}$ & Soybeans & Maize & $\begin{array}{l}\text { Other } \\
\text { Annual } \\
\text { Crops }\end{array}$ & Coffee & $\begin{array}{l}\text { Other Peren- } \\
\text { nial Crops }\end{array}$ & Milk & Wood & Beef & $\begin{array}{l}\text { Other Forest } \\
\text { Products }\end{array}$ \\
\hline Fuel quantity & $-9.40 e-6$ & $1.83 e-5^{*}$ & $* * * 1.02 e-5^{* * *}$ & $5.5 e-6$ & $2.5 e-6$ & $-3.93 e-5^{* * *}$ & $1.94 e-5^{* * * *}$ & $9.5 e-6$ & $4.93 e-6$ \\
\hline Land quantity & $-5.2 e-06^{* *}$ & $1.80 e-6^{*}$ & $* *-2.99 e-06^{* * *}$ & $2.4 e-6^{* * *}$ & $-3.0 e-7$ & $6.16 e-6^{* * *}$ & $2.9 e-7$ & $1.00 e-6$ & $-1.85 e-6^{* * * *}$ \\
\hline Irrigated area & $6.343^{* *}$ & $3.948^{* * *}$ & $-1.458^{* * *}$ & $3.992^{* * * *}$ & $-1.859 *$ & -0.451 & $-1.913^{* * *}$ & $-7.3^{* * *}$ & 0.708 \\
\hline Certified or & & & & & & & & & \\
\hline $\begin{array}{l}\text { transgenic seeds } \\
\text { Confined cattle }\end{array}$ & $\begin{array}{r}-0.962^{* *} \\
3.705^{* *}\end{array}$ & $\begin{array}{l}-0.114 \\
-0.460\end{array}$ & $\begin{array}{l}0.402^{* * *} \\
-0.301\end{array}$ & $\begin{array}{l}0.072 \\
0.358\end{array}$ & $\begin{array}{r}0.126 \\
-0.019\end{array}$ & $\begin{array}{r}0.393 \\
-0.421\end{array}$ & $\begin{array}{r}0.241 \\
-0.388\end{array}$ & $\begin{array}{l}-0.147 \\
-2.143\end{array} *$ & $\begin{array}{r}-0.071 \\
0.148\end{array}$ \\
\hline Tilled area & -0.957 & $-0.835^{* *}$ & -0.178 & -0.313 & -0.086 & $1.777^{* * *}$ & 0.203 & 0.499 & 0.308 \\
\hline Mech harvesting & 0.915 & -0.177 & -0.172 & -0.173 & $0.813^{* *}$ & -1.002 & 0.095 & -0.659 & 0.048 \\
\hline Rainfall in Summer & $0.0237^{* * * *}$ & $-4.6 E-04$ & $-9.80 E-07$ & $-0.00547 * *$ & $*-0.002 *$ & $-0.00893^{* * *}$ & $7.60 e-4$ & $-0.0058^{* * *}$ & $-2.8 e-4$ \\
\hline Rainfall in Winter & $0.0118^{* * *}$ & 0.0011 & $-0.0018^{* * *}$ & $-1.30 e-4$ & $-1.8 e-4$ & $-0.00827^{* * * *}$ & $-0.00221^{* * * *}$ & 0.0017 & $8.7 e-4$ \\
\hline $\begin{array}{l}\text { Temperature } \\
\text { in Summer } \\
\text { Temperature }\end{array}$ & $1.208^{* * * *}$ & $-0.207^{* *}$ & 0.067 & $-0.264 *$ & 0.0014 & -0.151 & 0.0806 & $-0.726^{* * *}$ & 0.0125 \\
\hline in Winter & $-0.464^{* * *}$ & 0.046 & -0.018 & $6.5 e E-4$ & 0.0234 & 0.0495 & 0.0063 & $0.352^{* * *}$ & 0.0113 \\
\hline
\end{tabular}


variable and each output considered $\left(\frac{\partial \ln \left(q_{j i}\right)}{\partial Z_{r i}^{1}}\right)$. The effects can be calculated by municipality when inputting municipal data into the marginal effect equation to identify the specific effects within the country. According to the estimated results (Table 3), soybean production increased when the Summer temperature was above average. Increases in the long-term average temperature during Summer by one degree Celsius could thus raise soybean production by $44 \%$ on average in the soybean-producing municipalities in Brazil. This effect is calculated based on $23 \%$ of the municipalities that presented statistically significant results and accounted for $96 \%$ of the soybean production. The same trend was observed for the average effect of rainfall during Summer and Winter. One possible explanation for this effect is that soybeans have greater yields in rainier municipalities during both Summer and Winter.

For most of the agricultural products analyzed, including maize, other annual crops, coffee, other perennial crops, milk, wood, and beef, municipalities with higher average rainfall during Summer and Winter had lower production. The average effects were not very high for many of these products. The products whose output was affected the most included milk during both Summer and Winter, coffee and other perennial crops during Summer, and wood during Winter. The results suggest that either these products are better adapted to more arid locations, or the higher rainfall averages during the Summer may have influenced the results.

The estimated impact of temperature appears to be much higher than that of precipitation. The partial effects of the higher Summer average temperature reduced the production of maize, other annual crops, coffee, other perennial crops, milk, and beef, while higher Winter temperatures adversely affected only coffee and soybeans.

\subsection{Climate Anomaly Impacts on Efficiency}

The null hypothesis that there were no inefficient components was rejected by the data ${ }^{18}$. Approximately half of the municipalities where the efficiency was calculated have a TE between 0.43 and 0.63 . The highest efficiency measured was 0.87 and the mean was 0.51 .

The complete results are described in Appendix B. Standard errors were generated by a bootstrap analysis with 1,000 replications. Multiple different model specifications were tested and no statistically significant difference was found among them, suggesting that the OLS approach is best suited for this analysis due to its simplicity and linearity.

The joint test for the significance of climate anomalies indicates that these variables are important to explain the differences in production efficiency among the municipalities. When droughts are defined as a binary variable equal to one when observed rainfall is two standard deviations below normal $(\alpha=2)$, results indicated that droughts reduced farmer efficiency during the Summer of 2005 by 0.068 , again in 2006 by 0.036 , and in the Winter of 2006 by 0.13 . The magnitude of these results is quite large compared to the previous effects discussed. The only season that showed a positive effect from droughts, or alternately a negative effect of floods was the Fall of 2006 which

18 The statistic of the z-test is 94.89 (p-value of 0.000 ), rejecting the null hypothesis of full efficiency. The test is based on Coelli (1995), who proposed a test in the third moment of the compound error distribution. 
Table 3: Semi-elasticities: average effect of climate variables on production by product and municipality from the 2006 census

\begin{tabular}{|c|c|c|c|c|c|c|}
\hline Output (j) & $\begin{array}{c}\text { Summer } \\
\% \text { Brazilian Munic. With } \\
\text { Stat. Sig. Effects }\end{array}$ & $\begin{array}{l}\% \text { Munic. With q>0 } \\
\text { and Stat. Sig. Effects }\end{array}$ & $\begin{array}{l}\text { Average Effect } \\
\text { for Brazil }\end{array}$ & $\begin{array}{c}\text { Winter } \\
\% \text { Brazilian Munic. With } \\
\text { Stat. Sig. Effects }\end{array}$ & $\begin{array}{l}\% \text { Munic. With q>0 } \\
\text { and Stat. Sig. Effects }\end{array}$ & $\begin{array}{l}\text { Average Effect } \\
\text { for Brazil }\end{array}$ \\
\hline \multicolumn{7}{|l|}{ Rainfall } \\
\hline $\begin{array}{l}\text { Soybeans } \\
\text { Maize } \\
\text { Other annual crops } \\
\text { Coffee } \\
\text { Other perennial crops } \\
\text { Milk } \\
\text { Wood } \\
\text { Beef } \\
\text { Other forest products }\end{array}$ & $\begin{array}{c}23 \% \\
4 \% \\
11 \% \\
30 \% \\
79 \% \\
93 \% \\
0 \% \\
94 \% \\
0 \%\end{array}$ & $\begin{array}{c}97 \% \\
4 \% \\
12 \% \\
97 \% \\
95 \% \\
97 \% \\
0 \% \\
99 \% \\
0 \%\end{array}$ & $\begin{array}{c}0.009 \\
-0.002 \\
-0.003 \\
-0.035 \\
-0.048 \\
-0.182 \\
0.000 \\
-0.017 \\
-3.1 e-5\end{array}$ & $\begin{array}{c}22 \% \\
3 \% \\
92 \% \\
2 \% \\
4 \% \\
93 \% \\
26 \% \\
4 \% \\
0 \%\end{array}$ & $\begin{array}{c}94 \% \\
4 \% \\
96 \% \\
7 \% \\
5 \% \\
98 \% \\
99 \% \\
4 \% \\
0 \%\end{array}$ & $\begin{array}{c}0.002 \\
-0.002 \\
-0.011 \\
-0.003 \\
-0.003 \\
-0.174 \\
-0.69 \\
2.9 e-4 \\
0.002\end{array}$ \\
\hline \multicolumn{7}{|l|}{ Temperature } \\
\hline $\begin{array}{l}\text { Soybeans } \\
\text { Maize } \\
\text { Other annual crops } \\
\text { Coffee } \\
\text { Other perennial crops } \\
\text { Milk } \\
\text { Wood } \\
\text { Beef } \\
\text { Other forest products }\end{array}$ & $\begin{array}{c}23 \% \\
78 \% \\
26 \% \\
24 \% \\
1 \% \\
2 \% \\
0 \% \\
96 \% \\
0 \%\end{array}$ & $\begin{array}{c}96 \% \\
87 \% \\
27 \% \\
79 \% \\
1 \% \\
2 \% \\
0 \% \\
100 \% \\
0 \%\end{array}$ & $\begin{array}{l}0.44 \\
-0.764 \\
-0.013 \\
-0.281 \\
-0.021 \\
-0.026 \\
0.00 e+0 \\
-1.87 \\
-4.7 e-4\end{array}$ & $\begin{array}{c}22 \% \\
2 \% \\
9 \% \\
1 \% \\
1 \% \\
1 \% \\
0 \% \\
96 \% \\
0 \%\end{array}$ & $\begin{array}{c}95 \% \\
2 \% \\
10 \% \\
4 \% \\
1 \% \\
1 \% \\
0 \% \\
100 \% \\
0 \%\end{array}$ & $\begin{array}{l}-0.227 \\
0.01 \\
0.002 \\
-0.024 \\
0.003 \\
0.002 \\
0.000 \\
0.9 \\
2.4 e-4\end{array}$ \\
\hline
\end{tabular}

Note:

The average effect for Brazil is calculated based on the weighted average of significant effects

(weighted by the production amount of the municipality) 
is harvest season for soybeans and maize. During such periods, floods are generally harmful, as confirmed by the estimated results. However, Fall is also the growing season for Winter crops such as wheat and triticale, which are adapted to the more temperate climate. The net result from both of these forces was positive.

In regard to the effects of cold stress on agriculture, colder temperatures in the Winter of 2006 and Spring of 2005 were found to be harmful to producers, decreasing efficiency by approximately 0.062 and 0.1 , respectively.

By using the estimated coefficients, the total profit loss or gain due to weather conditions in 2006 can be calculated by comparing the efficiency level when no anomalies occurred in rainfall or temperature in 2005 and 2006 $(C=0)$, the efficiency level considering the occurrence of the anomalies $(C$ is observed). Thus, the difference in efficiency $(\Delta T E)$ can be converted into the profit difference for each municipality in the sample. The impact of the 2005 and 2006 anomalies on TE $(\Delta T E)$ was calculated and transformed into variation in profits $(\Delta \Pi)$ according to the Equation (4):

$$
\Delta T E=\frac{\Delta \Pi(.)}{\Pi^{*}(.)} \therefore \Delta \Pi(.)=\Delta T E \Pi^{*}(.)=\Delta T E \frac{\Pi(.)}{T E}
$$

The change in profits was estimated by municipality, as well as the standard error of the estimates. Considering only the statistically significant effects by municipality, the average effect was a loss of profits due to rainfall anomalies at the end of 2005 and during the Fall of 2006 (Table 4). The total loss from decreased rainfall was estimated at 5.6\% of the farmers' current profits. This result reflects the drier Summer season observed both during 2005 throughout Brazil and during 2006 in the northeastern and southern regions and the state of Minas Gerais.

Table 4: Estimated impact of weather anomalies on profits in Brazil

\begin{tabular}{|c|c|c|c|}
\hline Estimates & $\%$ of Profits & $\begin{array}{l}\text { Loss }(-) \text { or Gain }(+) \text { in } \\
\text { Million Reais (Dec-06) }\end{array}$ & $\begin{array}{c}\text { Loss }(-) \text { or Gain }(+) \text { in } \\
\text { Million Dollars }\end{array}$ \\
\hline \multicolumn{4}{|c|}{2005 and 2006 anomalies } \\
\hline $\begin{array}{l}\text { Rainfall } \\
\text { Temperature }\end{array}$ & $\begin{array}{r}-5.60 \% \\
3.34 \%\end{array}$ & $\begin{array}{r}-21,440.70 \\
12,803.20\end{array}$ & $\begin{array}{r}-12,373.70 \\
5,127.82\end{array}$ \\
\hline \multicolumn{4}{|c|}{ Drought or cold stress } \\
\hline $\begin{array}{l}\text { Drought } \\
\text { Cold stress }\end{array}$ & $\begin{array}{l}-30.50 \% \\
-13.19 \%\end{array}$ & $\begin{array}{r}-116,689.10 \\
-50,474.20\end{array}$ & $\begin{array}{l}-67,342.75 \\
-29,129.30\end{array}$ \\
\hline \multicolumn{4}{|c|}{$\begin{array}{l}{[1] \text { Dollar amounts in January } 2014 \text { are calculated by updating the } 2006 \text { values }} \\
\text { using IPCA and converting it to dollars by the average exchange rate for } \\
1 / 1 / 2014 \\
\text { Source: Sisbacen PTAX800 }\end{array}$} \\
\hline
\end{tabular}

The estimated effect of temperature on profits showed a gain of 3.34\% due to the year-end 2005 and year-end 2006 temperature conditions. Because colder temperatures were more harmful to crops than warmer temperatures, the above-average temperatures in 2005 and 2006 had a positive impact on farm efficiency.

Following the same procedure, droughts and cold stresses were simulated in the country to determine the sensitivity of the losses. Assuming a two- 
standard deviation reduction in rainfall for droughts and in temperature for cold stress, the lost profit in each municipality was calculated. Considering only the statistically significant impacts, the total losses from these events were $13.2 \%$ and $30.5 \%$ for cold stress and droughts, respectively ${ }^{19}$. The estimates suggest that droughts are the most harmful climate anomaly in Brazilian agriculture. These effects are summarized below, as well as the calculation in terms of monetary losses.

The average loss of profits that farmers face under the occurrence of extreme weather events could be seen as a proxy for the farmers' maximum willingness to pay to protect themselves financially against drastic unforeseen weather changes. Thus, the willingness to pay for rainfall shortcomings in the country in 2006 was approximately 16.8 billion dollars, a considerable amount in terms of agricultural outcomes. The net effect, including the profit gain with increased temperature, was negative 7.2 billion dollars (in 2014 values). This result is very similar to the direct damage of climate anomalies on agriculture in 2005 calculated by Haddad et al. (2013). In regard to the expected losses by region, the Midwest and South regions were slightly more affected by both harmful climate anomalies than the other regions.

\section{Discussion and Conclusions}

The central idea of this study is that long-term climate influences the planning decision of producers, while short-term weather events are shocks which move actual production away from the planned production. This article employed a stochastic profit framework in the empirical analysis. Distinguishing between the effects of climate and weather in the production frontier framework is intuitively appealing. Still, it has not been well studied, as shown by the literature. Similarly, the theory of how stochastic frontiers models relate to long-term and short-term models of producer behavior is still just a caveat in the literature.

Thus, by using a translog profit frontier equation and data from the Agricultural Census of 2006 for Brazil, the average climate relevance on farmers' outcomes was tested. The marginal temperature effects calculated seemed to be much more significant than the decreased rainfall levels. The partial effects of higher average Summer temperatures reduced the production of maize and other annual crops such as rice, beans, manioc, and coffee, milk, beef and other perennial crops such as fruits. Places with higher Winter temperatures could suffer adverse effects on coffee and soybean output. Only soybean production was positively affected by higher Summer temperatures. A possible explanation for this result is the high adaptability of this crop to tropical regions.

The hypothesis of variation in technical efficiency levels was not rejected by the data, indicating that efficiency levels differ in a statistically significant way among Brazilian farmers. The estimation of the TE allowed for the modeling of possible determinants of the farmers' deviation from optimum choices, which can be imposed by exogenous forces. This article proposed climate anomalies as relevant determinants of farming inefficiency. The econometric test showed that climate anomalies are jointly relevant to explain the diffe-

\footnotetext{
${ }^{19}$ Droughts are assumed to be two-standard deviation negative anomalies in rainfall, while cold stress is assumed to be two standard deviation negative anomalies in temperature.
} 
rences in technical efficiencies. The average effect due to rainfall shortcomings on a farmer's TE during the Summer months of 2005 and 2006 was a 5.6\% reduction of the current farm profits, representing almost 12.4 billion dollars (values of 2014). This can be interpreted as the farmers' maximum willingness to pay to protect themselves against the unforeseen rainfall shortcomings in Brazil during 2006. The estimated temperature effects on profits showed a gain due to the year-end 2005 and year-end 2006 temperature conditions, in the order of $3.34 \%$ or 5.1 billion dollars.

The estimates of simulated cold stress and droughts throughout the country indicated lost profits of $13.2 \%$ to $30.5 \%$ respectively, and were slightly more intense in the Southern and Midwestern regions. These percentages represent 35 and 80 billion dollars of losses, respectively. Within this context, insurance is an important action to protect farmers from such harmful situations. Weather index insurance is gaining importance as a possible intervention technique to overcome the negative impacts of climate risk on rural livelihoods and agricultural production. Weather index insurance is normally linked to rainfall anomalies such as droughts and floods, extreme temperatures, extreme precipitation such as frosts, hail, and rainstorms, and even to crop yield thresholds (Iturrioz 2009).

The use of a weather index linked to an insurance mechanism could be a potential policy action related to a market-driven solution. Barnett \& Mahul (2007) also underlined the importance of understanding the mechanisms of weather impact on agricultural system models to design an index for this purpose. This article could be helpful in identifying the important relationships for the design of the index.

This study is innovative because it distinguishes between the effects of climate and weather on the production frontier framework by using a translog profit frontier equation. Additionally, the majority of Brazilian agricultural products were considered in the analysis, as well as many technological variables as quasi-fixed inputs inside a profit function approach. This study also used precise climate data from Brazilian weather stations, which allowed for the assessment of the impact of extreme weather events on agricultural outcomes. By using the method applied here, climate change effects can also be measured using data from INPE, and thus, compensation actions from the considered technological variables can be calculated.

\section{Acknowledgements}

This study was supported in part by CNPQ and Instituto Nacional de Ciencia e Tecnologia para Mudanças Climaticas/Rede CLIMA (Brazil). The authors would like to acknowledge the help and contributions of Professor Eduardo Haddad, Professor Bruno Giovannetti, Professor Marcos Rangel, Professor Andrea Lucchesi, the members of the IRI Summer Institute of 2011 at Columbia University, as well as the colleagues from the ICTP in Trieste, Italy. We also want to thank INPE and INMET for providing the data on climate forecast and observation, respectively. 


\section{Bibliography}

Ahmed, R. \& Hossain, M. (1990), Developmental Impact of Rural Infrastructure in Bangladesh, Vol. 83, Inter Food Policy Res Inst.

Ali, F., Parikh, A. \& Shah, M. (1994), 'Measurement of profit efficiency using behavioural and stochastic frontier approaches', Applied Economics 26(2), 181-188.

Ali, M. \& Flinn, J. C. (1989), 'Profit efficiency among Basmati rice producers in Pakistan Punjab', American Journal of Agricultural Economics 71(2), 303310 .

Barbosa, E. (2011), 'Climate change and the land use pattern in Brazil', $P h D$ thesis, University of São Paulo .

Barnett, B. J. \& Mahul, O. (2007), 'Weather index insurance for agriculture and rural areas in lower-income countries', American Journal of Agricultural Economics 89(5), 1241-1247.

Barrett, C. B. (1996), 'On price risk and the inverse farm size-productivity relationship', Journal of Development Economics 51(2), 193-215.

Battese, G. E. \& Coelli, T. J. (1995), 'A model for technical inefficiency effects in a stochastic frontier production function for panel data', Empirical Economics 20(2), 325-332.

Bozoğlu, M. \& Ceyhan, V. (2007), 'Measuring the technical efficiency and exploring the inefficiency determinants of vegetable farms in Samsun province, Turkey', Agricultural Systems 94(3), 649-656.

Christensen, L. R., Jorgenson, D. W. \& Lau, L. J. (1975), 'Transcendental logarithmic utility functions', The American Economic Review 65(3), 367-383.

Coelli, T. J. (1995), 'Recent developments in frontier modelling and efficiency measurement', Australian Journal of Agricultural and Resource Economics 39(3), 219-245.

Cunha, D. A., Coelho, A. B., Féres, J. G. \& Braga, M. J. (2014), 'Effects of climate change on irrigation adoption in Brazil', Acta Scientiarum Agronomy 36(1), 1-9.

DeGroot, M. H. \& Schervish, M. J. (2012), Probability and Statistics, Pearson Education.

Demir, N. \& Mahmud, S. F. (2002), 'Agro-climatic conditions and regional technical inefficiencies in agriculture', Canadian Journal of Agricultural Economics/Revue Canadienne D'agroeconomie 50(3), 269-280.

Deschenes, O. \& Greenstone, M. (2007), 'The economic impacts of climate change: evidence from agricultural output and random fluctuations in weather', American Economic Review 97(1), 354-385.

Disch, A. (1985), 'Agricultural policies and real income changes: an application of duality theory to Brazilian agriculture'. 
Fisher, A. C., Hanemann, W. M., Roberts, M. J. \& Schlenker, W. (2012), 'The economic impacts of climate change: evidence from agricultural output and random fluctuations in weather: comment', American Economic Review 102(7), 3749-60.

Gorton, M. \& Davidova, S. (2004), 'Farm productivity and efficiency in the cee applicant countries: a synthesis of results', Agricultural Economics 30(1), 1-16.

Haas, T. C. (1990), 'Kriging and automated variogram modeling within a moving window', Atmospheric Environment, Part A, General Topics 24(7), 1759-1769.

Haddad, E., Porsse, A. \& Pereda, P. (2013), 'Territorial economic impacts of climate anomalies in Brazil', Revista Brasileira de Estudos Regionais e Urbanos $7(2)$.

Helfand, S. M. (2003), 'Os determinantes da eficiência técnica no CentroOeste brasileiro', Região e Espaço no Desenvolvimento Agrícola Brasileiro, Rio de Janeiro, IPEA/NEMESIS .

Imori, D., Guilhoto, J. \& Postali, F. (2012), 'Production efficiency of family farms and business farms in the Brazilian regions'.

IPCC (2007), 'Report of the nineteenth session of the Intergovernmental Panel on Climate Change (IPCC) Geneva, 17-20 (am only) April 2002'.

Iturrioz, R. (2009), 'Agricultural insurance. Primer series on insurance', The World Bank Working Paper 12 .

Kum-bhakar, S. \& Lovell, C. (2000), 'Stochastic frontier analysis Cambridge University Press Cambridge Google Scholar'.

Kumar, K. K. \& Parikh, J. (2001), 'Indian agriculture and climate sensitivity', Global Environmental Change 11(2), 147-154.

Lang, G. (2001), 'Global warming and German agriculture impact estimations using a restricted profit function', Environmental and Resource Economics 19(2), 97-112.

Mendelsohn, R., Nordhaus, W. D. \& Shaw, D. (1994), 'The impact of global warming on agriculture: a Ricardian analysis', The American Economic Review pp. 753-771.

Pastore, A. C. (1968), 'A resposta da propriedade agrícola aos preços no Brasil', São Paulo, Faculdade de Economia e Administração/USP .

Rahman, S. (2005), 'Environmental impacts of technological change in Bangladesh agriculture: farmers' perceptions, determinants, and effects on resource allocation decisions', Agricultural Economics 33(1), 107-116.

Rahman, S. \& Parkinson, R. (2007), 'Productivity and soil fertility relationships in rice production systems, Bangladesh', Agricultural Systems 92(13), 318-333. 
Rausser, G. C. \& Just, R. E. (1981), 'Principles of policy modeling in agriculture'.

Rosenzweig, M. R. \& Binswanger, H. P. (1993), 'Wealth, weather risk and the composition and profitability of agricultural investments', Economic Journal 103(416), 56-78.

Rosenzweig, M. R. \& Wolpin, K. I. (1993), 'Credit market constraints, consumption smoothing, and the accumulation of durable production assets in low-income countries: investments in bullocks in India', Journal of Political Economy 101(2), 223-244.

Seo, S. N. (2010), 'A microeconometric analysis of adapting portfolios to climate change: adoption of agricultural systems in Latin America', Applied Economic Perspectives and Policy 32(3), 489-514.

Seo, S. N. (2011), 'An analysis of public adaptation to climate change using agricultural water schemes in South America', Ecological Economics 70(4), 825-834.

Seo, S. N. \& Mendelsohn, R. O. (2007), A Ricardian Analysis of the Impact of Climate Change on Latin American Farms, Vol. 4163, World Bank Publications.

Sherlund, S. M., Barrett, C. B. \& Adesina, A. A. (2002), 'Smallholder technical efficiency controlling for environmental production conditions', Journal of Development Economics 69(1), 85-101.

Tzouvelekas, V., Pantzios, C. J. \& Fotopoulos, C. (2001), 'Technical efficiency of alternative farming systems: the case of Greek organic and conventional olive-growing farms', Food Policy 26(6), 549-569.

Valor-Econômico (2012), 'Perda agrícola com seca soma quase 1 bi de Reais no RS e em SC', Valor Econômico .

Wang, J., Wailes, E. J. \& Cramer, G. L. (1996), 'A shadow-price frontier measurement of profit efficiency in Chinese agriculture', American Journal of Agricultural Economics 78(1), 146-156.

Wilson, P., Hadley, D. \& Asby, C. (2001), 'The influence of management characteristics on the technical efficiency of wheat farmers in eastern England', Agricultural Economics 24(3), 329-338.

Xu, X. \& Jeffrey, S. R. (1998), 'Efficiency and technical progress in traditional and modern agriculture: evidence from rice production in China', Agricultural Economics 18(2), 157-165. 


\section{Appendix A}

Table 5: Descriptive statistics

\begin{tabular}{|c|c|c|c|c|c|}
\hline Variable & Total Obs. & Mean & Std. Dev. & Min & Max \\
\hline \multicolumn{6}{|l|}{ Information on Agricultural Production } \\
\hline Maize (tonnes) & 5548 & $6,826.75$ & $25,470.49$ & 0 & 596,645 \\
\hline Soybeans (tonnes) & 5548 & $7,057.82$ & $37,722.83$ & 0 & $1,360,187$ \\
\hline Other annual crops (tonnes) & 5548 & $75,534.18$ & $343,187.50$ & 0 & $7,330,239$ \\
\hline Coffee (tonnes) & 5548 & 463.31 & $2,244.40$ & 0 & 67,361 \\
\hline Other perennial crops (tonnes) & 5548 & $3,855.21$ & $18,816.18$ & 0 & 479,138 \\
\hline Wood $\left(m^{3}\right)$ & 5548 & 7.34 & 53.93 & 0 & 1,675 \\
\hline Other forest products (tonnes) & 5548 & 160.58 & $2,148.29$ & 0 & 131,572 \\
\hline Milk (thd liters) & 5548 & $3,057.84$ & $5,776.21$ & 0 & 125,104 \\
\hline Beef amount (cattle) & 5532 & 604.93 & 948.66 & 0 & 10,565 \\
\hline \multicolumn{6}{|l|}{ Input prices (Thd reais per employee or hectares) } \\
\hline Labor price & 5552 & 1.09 & 2.67 & 0 & 48.25 \\
\hline Price per fertilized hectare & 5552 & 0.24 & 0.32 & 0 & 4.89 \\
\hline \multicolumn{6}{|l|}{$\begin{array}{l}\text { Input quantities (in thousand Kcal/ } \\
\text { hectares/employees) }\end{array}$} \\
\hline Total fuel (in k Kcal) & 5548 & 4,715 & 9,715 & 0 & 233,783 \\
\hline Total available land (ha) & 5548 & 41,602 & 86,862 & 0 & $3,719,038$ \\
\hline Total employees (number) & 5548 & 4,698 & 7,761 & 0 & 306,279 \\
\hline Total fertilized area (ha) & 5548 & 7,240 & 21,934 & 0 & 595,488 \\
\hline \multicolumn{6}{|l|}{ Technological Information Regarding Production } \\
\hline Percentage of mechanical harvesting & 5548 & 0.03 & 0.13 & 0 & 1 \\
\hline Percentage of certified seeds & 5548 & 0.30 & 0.32 & 0 & 1 \\
\hline Percentage of transgenic seeds & 5548 & 0.04 & 0.11 & 0 & 1 \\
\hline Percentage of certified or transgenic seeds usage & 5548 & 0.33 & 0.35 & 0 & 1 \\
\hline Percentage of cattle confined & 5548 & 0.03 & 0.07 & 0 & 1 \\
\hline Percentage of artificial insemination & 5427 & 0.08 & 0.14 & 0 & 1 \\
\hline Percentage of tilled area & 4691 & 0.07 & 0.16 & 0 & 0.89 \\
\hline Percentage of irrigated area & 5544 & 0.02 & 0.06 & 0 & 0.64 \\
\hline Percentage of animal tracking & 5548 & 0.05 & 0.07 & 0 & 1 \\
\hline Percentage of industrial feed usage & 5548 & 0.01 & 0.03 & 0 & 0.5 \\
\hline \multicolumn{6}{|l|}{ Other variables } \\
\hline$\%$ of farmers in cooperative associations & 5547 & 0.245 & 0.201 & 0 & 1 \\
\hline$\%$ of farmers that own the land & 5547 & 0.798 & 0.18 & 0 & 1 \\
\hline$\%$ of tenant farmers & 5547 & 0.045 & 0.064 & 0 & 1 \\
\hline$\%$ of farms that use pest control & 5547 & 0.113 & 0.134 & 0 & 1 \\
\hline$\%$ of population with 0 to 4 years of schooling & 5548 & 63.314 & 9.812 & 26 & 90.62 \\
\hline$\%$ of population with 5 to 8 years of schooling & 5548 & 15.653 & 3.113 & 4.33 & 35.13 \\
\hline$\%$ of population with 9 to 11 years of schooling & 5548 & 16.433 & 5.583 & 1.52 & 40.88 \\
\hline$\%$ of population $>12$ years of schooling & 5548 & 4.169 & 2.613 & 0.18 & 26.69 \\
\hline$\%$ of population with undetermined schooling & 5548 & 0.431 & 0.516 & 0 & 6.48 \\
\hline$\%$ of farmers that used any credit & 5547 & 0.180 & 0.144 & 0 & 0.85 \\
\hline Altitude (in meters) & 5499 & 412.310 & 293.07 & 0 & 1628 \\
\hline Average size of farms (in hectare) & 5543 & 34.343 & 79.918 & 0 & 1561.98 \\
\hline Agricultural HHI & 5546 & 0.462 & 0.21 & 0 & 1 \\
\hline$\%$ of female farmers & 5547 & 10.977 & 6.349 & 0 & 100 \\
\hline$\%$ of farmers 1 to 5 years of experience & 5547 & 17.995 & 8.196 & 0 & 100 \\
\hline$\%$ of farmers 5 to 10 years of experience & 5547 & 18.539 & 8.002 & 0 & 100 \\
\hline$\%$ of farmers $>10$ years of experience & 5547 & 60.485 & 13.735 & 0 & 100 \\
\hline$\%$ of family farms & 5547 & 78.568 & 15.424 & 0 & 100 \\
\hline Index for logistic cost to São Paulo & 5547 & 0.299 & 3.381 & 0 & 100 \\
\hline Degraded agricultural are (in hectares) & 5543 & 0.003 & 0.01 & 0 & 0.48 \\
\hline
\end{tabular}




\section{Appendix B}

Table 6: Results from the estimated profit equation

\begin{tabular}{|c|c|c|c|}
\hline Variables & OLS & TOBIT & $\mathbf{G L M}^{[1]}$ \\
\hline$\%$ of farmers in cooperative associations & $0.0790^{* * *}$ & $0.0790^{* * *}$ & $0.0802^{* * *}$ \\
\hline$\%$ of farmers that own the land & -0.00544 & -0.00544 & -0.00545 \\
\hline$\%$ of tenant farmers & $0.162^{* * *}$ & $0.162^{* * *}$ & $0.165^{* * *}$ \\
\hline$\%$ of farms that use pest control & 0.0116 & 0.0116 & 0.0117 \\
\hline$\%$ of population with 0 to 4 years of schooling & $-0.00773^{* * *}$ & $-0.00773^{* * *}$ & $-0.00783^{* * *}$ \\
\hline$\%$ of population with 5 to 8 years of schooling & $-0.00632^{* * *}$ & $-0.00632^{* * *}$ & $-0.00640^{* * *}$ \\
\hline$\%$ of population with 9 to 11 years of schooling & $-0.0111^{* * *}$ & $-0.0111^{* * *}$ & $-0.0113^{* * *}$ \\
\hline$\%$ of population $>12$ years of schooling & 0.000658 & 0.000658 & 0.000714 \\
\hline$\%$ of population with undetermined schooling & $0.0588^{* *}$ & $0.0588^{* *}$ & $0.0596^{* *}$ \\
\hline$\%$ of farmers that used any credit & $3.20 E-06$ & $3.20 e-6$ & $3.30 e-6$ \\
\hline Altitude & $-0.00050^{* * *}$ & $-0.00050^{* * *}$ & $-0.00051^{* * *}$ \\
\hline Average size of farms (in hectare) & $3.98 E-07^{* * *}$ & $3.98 E-07^{* * *}$ & $.11 E-07^{* * *}$ \\
\hline Agricultural HHI & $0.222^{* * *}$ & $0.222^{* * *}$ & $0.226^{* * *}$ \\
\hline$\%$ of female farmers & $3.58 E-05$ & $3.58 E-05$ & $4.10 E-05$ \\
\hline$\%$ of farmers 1 to 5 years of experience & -0.000463 & -0.000463 & -0.000465 \\
\hline$\%$ of farmers 5 to 10 years of experience & 0.000407 & 0.000407 & 0.000417 \\
\hline$\%$ of farmers $>10$ years of experience & $7.11 E-05$ & $7.11 E-05$ & $7.41 E-05$ \\
\hline$\%$ of family farms & $0.00102^{* * *}$ & $0.00102^{* * *}$ & $0.00103^{* * *}$ \\
\hline Index for logistic cost to Sao Paulo & -0.0582 & -0.0582 & -0.0589 \\
\hline Degraded agricultural are (in hectares) & -0.223 & -0.223 & -0.229 \\
\hline$[$ Rainfall $-\mathrm{E}($ Rainfall $)] / \sigma$ in the Summer of 2006 & $0.0181 *$ & $0.0181 *$ & $0.0184 *$ \\
\hline$[$ Rainfall - E(Rainfall)]/ $\sigma$ in the Summer of 2005 & $0.0340^{* * *}$ & $0.0340^{* * *}$ & $0.0346^{* * *}$ \\
\hline [Rainfall - E(Rainfall)]/ $\sigma$ in the Fall of 2006 & $-0.0341^{* * *}$ & $-0.0341^{* * *}$ & $-0.0345^{* * *}$ \\
\hline$[$ Rainfall - E(Rainfall)] $\sigma$ in the Fall of 2005 & -0.012 & -0.012 & -0.0122 \\
\hline [Rainfall - E(Rainfall)]/ $\sigma$ in the Winter of 2006 & $0.0654^{* * *}$ & $0.0654^{* * *}$ & $0.0663^{* * *}$ \\
\hline$[$ Rainfall $-\mathrm{E}($ Rainfall $)] / \sigma$ in the Winter of 2005 & -0.00472 & -0.00472 & -0.00486 \\
\hline [Rainfall - E(Rainfall)]/ $\sigma$ in the Spring of 2006 & -0.0108 & -0.0108 & -0.011 \\
\hline$[$ Rainfall - E(Rainfall $)] / \sigma$ in the Spring of 2005 & 0.00176 & 0.00176 & 0.00172 \\
\hline$[$ Temperature $-\mathrm{E}($ Temp $)] / \sigma$ in the Summer of 2006 & -0.000871 & -0.000871 & -0.000776 \\
\hline$[$ Temperature $-\mathrm{E}($ Temp)] $/ \sigma$ in the Summer of 2005 & 0.00325 & 0.00325 & 0.0033 \\
\hline$[$ Temperature $-\mathrm{E}(\mathrm{Temp})] / \sigma$ in the Fall of 2006 & -0.0218 & -0.0218 & -0.0221 \\
\hline$[$ Temperature $-\mathrm{E}(\mathrm{Temp})] / \sigma$ in the Fall of 2005 & -0.0208 & -0.0208 & -0.021 \\
\hline [Temperature - E(Temp)]/ $\sigma$ in the Winter of 2006 & $0.0310^{* *}$ & $0.0310^{* *}$ & $0.0315^{* *}$ \\
\hline$[$ Temperature $-\mathrm{E}(\mathrm{Temp})] / \sigma$ in the Winter of 2005 & $-0.0448^{* * *}$ & $-0.0448^{* * *}$ & $-0.0455^{* * *}$ \\
\hline$[$ Temperature - E(Temp)]/ $\sigma$ in the Spring of 2006 & -0.0168 & -0.0168 & -0.0172 \\
\hline [Temperature - E(Temp)]/ $\sigma$ in the Spring of 2005 & $0.0499^{* * *}$ & $0.0499^{* * *}$ & $0.0506^{* * *}$ \\
\hline Sigma (Tobit model) & & $0.147^{* * *}$ & \\
\hline Constant & $1.119 * * *$ & $1.119^{* * *}$ & \\
\hline \multicolumn{4}{|l|}{ Test for climate variable ${ }^{[2]}$ : } \\
\hline Chi-sq(16) & $109.78^{* * *}$ & $112.84^{* * *}$ & $112.47^{* * *}$ \\
\hline Observations & 4,473 & 4,473 & 4,473 \\
\hline AIC & -4376.22 & -4374.22 & 0.95 \\
\hline $\mathrm{BIC}$ & -4139.2 & -4130.8 & $-36,875.54$ \\
\hline log-likelihood & & 2225.11 & -2094.28 \\
\hline
\end{tabular}


